\title{
Kedudukan Hukum Islam Dalam Sistem Hukum Nasional
}

\author{
Mardani \\ F.H. Universitas Krisnadwipayana Jakarta \\ dani_dr@telkom.net
}

\begin{abstract}
For the purpose of the development of national legal system, Islamic law has paid significant contribution, at least in terms of the spirit. During decades, Islamic law has experienced significant development. The opportunity for the penetration of more aspects of Islamic law into Indonesian legal system is in positive trend.
\end{abstract}

Keywords: Islamic Law, Islamic/Religious Court, National Legal System

\section{Pendahuluan}

Dalam membicarakan Hukum Islam di tengah-tengah Hukum Nasional pusat perhatian akan ditujukan pada kedudukan Hukum Islam dalam sistem Hukum Nasional. Sistem Hukum Indonesia, sebagai akibat dari perkembangan sejarahnya bersifat majemuk. Disebut demikian karena sampai sekarang di negara Republik Indonesia berlaku beberapa sistem hukum yang mempunyai corak dan susunan sendiri. Sistem hukum itu adalah sistem hukum Adat, sistem hukum Islam dan sistem hukum Barat.

Sejak awal kehadiran Islam pada abad ke tujuh Masehi tata hukum Islam sudah dipraktikkan dan dikembangkan dalam lingkungan masyarakat dan peradilan Islam. Hamka mengajukan fakta berbagai karya ahli Hukum Islam Indonesia. Misalnya Shirat al-Thullab, Shirat alMustaqim, Sabil al-Muhtadin, Kartagama, Syainat al-Hukm, dan lain-lain. ${ }^{1}$ Akan tetapi semua karya tulis tersebut masih bercorak pembahasan fiqih, masih bersifat doktrin hukum dan sistem fiqih Indonesia yang berorientasi kepada ajaran Imam Mazhab.

${ }^{1}$ Hamka, Antara Fakta dan Khayal "Tuanku Rao", Jakarta: Bulan Bintang, 1974, hlm. 324 
Pada era kekuasaan kesultanan dan kerajaan-kerajaan Islam peradilan agama sudah hadir secara formal. Ada yang bernama peradilan penghulu seperti di Jawa. Mahkamah Syar'iyah di Kesultanan Islam di Sumatera. Peradilan Qadi di Kesultanan Banjar dan Pontianak. Namun sangat disayangkan, walaupun pada masa Kesultanan telah berdiri secara formal peradilan Agama serta status ulama memegang peranan sebagai penasehat dan hakim, belum pernah disusun suatu buku hukum positif yang sistematik. Hukum yang diterapkan masih abstraksi yang ditarik dari kandungan doktrin fiqih.

Baru pada tahun 1760 VOC memerintahkan D.W. Freijer untuk menyusun hukum yang kemudian dikenal dengan Compendium Freijer. Compendium ini dijadikan rujukan hukum dalam menyelesaikan sengketa yang terjadi dikalangan masyarakat Islam di daerah yang dikuasai VOC. ${ }^{2}$

Penggunaan Compendium Freijer tidak berlangsung lama. Pada tahun 1800 VOC menyerahkan kekuasaan kepada Pemerintah Hindia Belanda. Bersamaan dengan itu lenyap dan tenggelam compendium itu. Lahirlah politik hukum baru, yang didasarkan atas teori resepsi atau teori konflik Snouck Hurgronje dan van Vollenhoven. Sejak itu secara sistematik, dengan senjaga hukum Islam dipencilkan. Sebagai gantinya digunakan dan ditampilkan hukum adat. Pemerintah Hindia Belanda mencoba melaksanakan hanya dua sistem hukum yang berlaku, yaitu hukum adat untuk golongan Bumiputera dan hukum barat bagi golongan Eropa.

Upaya paksaan untuk melenyapkan peran hukum Islam, terakhir ditetapkan dalam Staatsblad 1937 Nomor 116. Aturan ini merupakan hasil usaha komisi Ter Haar, yang di dalamnya memuat rekomendasi: (1) Hukum kewarisan Islam belum diterima sepenuhnya oleh masyarakat. (2) Mencabut wewenang Peradilan Agama (Raad Agama) untuk mengadili perkara kewarisan, dan wewenang ini dialihkan kepada Landraad. (3) Pengadilan Agama ditempatkan di bawah pengawasan Landraad. (4) Putusan Pengadilan Agama tidak dapat dilaksanakan tanpa executoir verklaring dari ketua Landraad. ${ }^{3}$

Setelah Indonesia merdeka, walaupun aturan peralihan menyatakan bahwa hukum yang lama masih berlaku selama jiwanya tidak

\footnotetext{
${ }^{2}$ Supomo dan Djoko Sutowo, Sejarah Politik Hukum Adat 1609 - 1848, Jakarta: Djambatan 1955, hlm. 26

${ }^{3}$ M. Yahya Harahap, Informasi Materi Kompilasi Hukum Islam: "Mempositifkan Abstraksi Hukum Islam", dalam, Kompilasi Hukum Islam dan Peradilan Agama dalam Sistem Hukum Nasional, Jakarta, Logos, 1999, hlm. 27
} 
bertentangan dengan UUD 1945, seluruh peraturan pemerintahan Belanda yang berdasarkan teori receptie tidak berlaku lagi karena jiwanya bertentangan dengan UUD 1945. Teori receptie harus exit karena bertentangan dengan al-Qur'an dan sunnah Rasul. ${ }^{4}$ Hazairin menyebut teori receptie sebagai teori Iblis.

Berdasarkan pendapatnya ini, Hazairin mengembangkan teori yang disebutnya sebagai teori receptie exit. Pokok-pokok pikiran Hazairin tersebut adalah: ${ }^{5}$ 1) Teori receptie telah patah, tidak berlaku dan exit dari tata negara Indonesia sejak tahun 1945 dengan merdekanya bangsa Indonesia dan mulai berlakunya UUD 1945. 2) Sesuai dengan UUD 1945 Pasal 29 ayat 1 maka negara Republik Indonesia berkewajiban, membentuk hukum nasional Indonesia yang bahannya hukum agama. Negara mempunyai kewajiban kenegaraan untuk itu. 3) Hukum agama yang masuk dan menjadi hukum nasional Indonesia bukan hukum Islam saja, melainkan juga hukum agama lain untuk pemeluk agama lain. Hukum agama di bidang hukum perdata diserap dan hukum pidana diserap menjadi hukum nasional Indonesia. Itulah hukum baru Indonesia dengan dasar Pancasila.

Di samping Hazairin, seorang tokoh yang juga menentang teori receptie adalah Sayuti Thalib yang menulis buku Receptie a Contrario: Hubungan Hukum Adat dengan Hukum Islam. Teori ini mengandung sebuah pemikiran bahwa, hukum adat baru berlaku kalau tidak bertentangan dengan hukum Islam. Melalui teori ini jiwa pembukaan dan UUD 1945 telah mengalahkan Pasal 134 ayat 2 Indische Staatsregling itu. ${ }^{6}$

Menurut Ismail Sunny setelah Indonesia merdeka dan UUD 1945 berlaku sebagai dasar negara kendati tanpa memuat ketujuh kata dari Piagam Jakarta maka teori receptie dinyatakan tidak berlaku lagi dan kehilangan dasar hukumnya. Selanjutnya hukum Islam berlaku bagi bangsa Indonesia yang beragama Islam sesuai dengan pasal 29 UUD 1945. Era ini disebut Sunny sebagai Periode Penerimaan Hukum Islam sebagai sumber Persuasif (Persuasive source). ${ }^{7}$

${ }^{4}$ Ichtijanto, "Pengembangan Teori Berlakunya Hukum Islam di Indonesia", dalam, Hukum Islam di Indonesia Perkembangan dan Pembentukan, Bandung: Rosdakarya, 1991, hlm. 128

${ }^{5}$ Amiur Nuruddin dan Azhari Akmal Tarigan, Hukum Perdata Islam di Indonesia, Jakarta: Kencana, 2004, hlm. 17

${ }^{6}$ Sayuti Thalib, Receptie a Contrario, Jakarta: Bina Aksara, 1985, hlm. .37-40

${ }^{7}$ Ismail Sunny, "Tradisi dan Inovasi Keislaman di Indonesia dalam Bidang Hukum Islam", dalam, Hukum Islam dalam Tatanan Masyarakat Indonesia, Cik Hasan Bisri (ed), Jakarta: Logos Publishing, 1988, hlm. 96 
Selanjutnya dengan ditempatkannya Piagam Jakarta dalam Dekrit Presiden RI tanggal 5 Juli 1959, maka era ini dapat dikatakan era penerimaan hukum Islam sebagai sumber otoritatif (authoritative source). Sehingga sering kali disebut bahwa Piagam Jakarta menjiwai UndangUndang Dasar 1945 dan merupakan suatu rangkaian kesatuan dalam konstitusi tersebut. Kata menjiwai bisa bermakna negatif dalam arti tidak boleh dibuat perundang-undangan dalam negara RI yang bertentangan dengan syari' at Islam bagi pemeluk-pemeluknya. Secara positif maknanya adalah pemeluk-pemeluk yang beragama Islam diwajibkan menjalankan syari'at Islam. Untuk itu diperlukan undang-undang yang akan memberlakukan hukum Islam dalam hukum nasional.

\section{Hukum Islam}

Kata hukum Islam tidak ditemukan sama sekali di dalam al-Qur'an dan literatur hukum dalam Islam. Yang ada dalam al-Qur'an adalah kata syari'ah, fiqh, hukum Allah dan yang seakar dengannya. Kata-kata hukum Islam merupakan terjemahan dari term "Islamic Law" dari literatur Barat.

Dalam penjelasan tentang hukum Islam dari literatur Barat ditemukan definisi hukum Islam yaitu: keseluruhan kitab Allah yang mengatur kehidupan setiap muslim dalam segala aspeknya. ${ }^{8}$ Dari definisi ini arti hukum Islam lebih dekat dengan pengertian syariah.

Hasbi Asy-Syiddiqy memberikan definisi hukum Islam dengan “koleksi daya upaya fuqaha dalam menerapkan syari'at Islam sesuai dengan kebutuhan masyarakat". ${ }^{9}$ Pengertian hukum Islam dalam definisi ini mendekati kepada makna fiqh.

Untuk lebih memberikan kejelasan tentang arti hukum Islam, perlu diketahui lebih dahulu arti dari kata "hukum". Sebenarnya tidak ada arti yang sempurna tentang hukum. Namun, untuk mendekatkan kepada pengertian yang mudah dipahami, meski masih mengandung kelemahan, definisi yang diambil oleh Muhammad Muslehuddin dari Oxford English Dictionary perlu diungkapkan. Menurutnya, hukum adalah "the body of rules, wether proceeding from formal enactment or from custom, which a particular state or community recognizes as binding on its

\footnotetext{
${ }^{8}$ Lihat Joseph Schacht, An Introduction to Islamic Law, Oxford: University Press, 1964, hlm. 1

${ }^{9}$ Muhammad Hasbi Ash-Shiddiqy, Falsafah Hukum Islam, Jakarta: Bulan Bintang, 1993, hlm. 44
} 
members or subjects"..$^{10}$ (Sekumpulan aturan, baik yang berasal dari aturan formal maupun adat, yang diakui oleh masyarakat dan bangsa tertentu sebagai mengikat bagi anggotanya).

Bila hukum dihubungkan dengan Islam, maka hukum Islam berarti: "Seperangkat peraturan berdasarkan wahyu Allah dan Sunnah Rasul tentang tingkah laku manusia mukallaf yang diakui dan diyakini berlaku dan mengikat untuk semua umat yang beragama Islam" ${ }^{11}$

Dari definisi yang dikemukakan di atas dapat dipahami bahwa hukum Islam mencakup Hukum Syari'ah dan Hukum Fiqh, karena arti syarak dan fiqh terkandung di dalamnya.

\section{Hukum Nasional}

Hukum nasional adalah hukum yang dibangun oleh bangsa Indonesia, setelah Indonesia merdeka dan berlaku bagi penduduk Indonesia, terutama bagi warga negara Republik Indonesia sebagai pengganti hukum kolonial.

Untuk mewujudkan satu hukum nasional bagi bangsa Indonesia yang terdiri atas berbagai suku bangsa dengan budaya dan agama yang berbeda, ditambah dengan keanekaragaman hukum yang ditinggalkan oleh pemerintah kolonial dahulu, bukan pekerjaan mudah. Pembangunan hukum nasional akan berlaku bagi semua warga negara tanpa memandang agama yang dipeluknya harus dilakukan dengan hati-hati, karena di antara agama yang dipeluk oleh warga negara Republik Indonesia ini ada agama yang tidak dapat diceraipisahkan dari hukum. Agama Islam, misalnya, adalah agama yang mengandung hukum yang mengatur hubungan manusia dengan manusia lain dan benda dalam masyarakat. Bahwa Islam adalah agama hukum dalam arti kata yang sesungguhnya. Oleh karena itu, dalam pembangunan hukum nasional di negara yang mayoritas penduduknya beragama Islam seperti di Indonesia ini, unsur-unsur hukum agama itu harus benar-benar diperhatikan. Untuk itu perlu wawasan yang jelas dan kebijakan yang arif.

Karena hukum nasional harus mampu mengayomi dan memayungi seluruh bangsa dan negara dalam segala aspek kehidupannya, maka menurut Menteri Kehakiman Ismail Saleh (1989) dalam merencanakan

${ }^{10}$ AS. Honrby, Oxford Advanced Learner's Dictionary of Current English, Britain: Oxford University Press, 1986, hlm. 478

${ }^{11}$ Amir Syarifuddin, "Pengertian dan Sumber Hukum Islam", dalam Falsafah Hukum Islam, Jakarta: Bumi Aksara, 1992, hlm. 14. 
pembangunan hukum nasional, kita wajib menggunakan wawasan nasional yang merupakan tritunggal yang tidak dapat dipisahkan satu dari yang lain, yaitu: wawasan kebangsaan, wawasan nusantara dan wawasan bhineka tunggal ika.

Dipandang dari wawasan kebangsaan sistem hukum nasional harus berorientasi penuh pada aspirasi serta kepentingan bangsa Indonesia. Wawasan kebangsaan ini, menurut Menteri Kehakiman, bukanlah wawasan kebangsaan yang tertutup, tetapi terbuka memperhatikan kepentingan generasi yang akan datang dan mampu menyerap nilai-nilai hukum modern. ${ }^{12}$

Karena yang dianut dalam pembangunan hukum nasional juga wawasan nusantara yang menginginkan adanya satu hukum nasional, maka usaha unifikasi di bidang hukum harus sejauh mungkin dilaksanakan. Ini berarti seluruh golongan masyarakat akan diatur oleh satu sistem hukum yaitu sistem hukum nasional. Akan tetapi, demi keadilan, kata Menteri Kehakiman, hukum nasional yang akan diwujudkan berdasarkan kedua wawasan itu, harus juga memperhatikan perbedaan latar belakang sosial budaya dan kebutuhan hukum yang dimiliki oleh kelompok-kelompok tertentu dalam masyarakat. Oleh karena itu, di samping kedua wawasan tersebut, pembangunan hukum nasional harus mempergunakan wawasan bhinneka tunggal ika. Dengan mempergunakan wawasan tersebut, unifikasi hukum yang diinginkan oleh wawasan nusantara itu harus menjamin tertuangnya aspirasi, nilai-nilai dan kebutuhan hubungan masyarakat ke dalam sistem hukum nasional. Dengan wawasan Bhinneka Tunggal Ika ini, keragaman suku bangsa, budaya dan agama sebagai aset pembangunan nasional harus dihormati, sepanjang, tentu saja, tidak membahayakan persatuan dan kesatuan bangsa.

Dengan mempergunakan ketiga wawasan itu, secara serentak dan terpadu berbagai asas dan kaidah hukum Islam, juga hukum Adat dan hukum eks Barat akan menjadi integral hukum nasional, baik hukum nasional yang tertulis maupun hukum nasional yang tidak tertulis atau hukum kebiasaan.

Mengenai kedudukan hukum Islam, yang telah disinggung di atas, Menteri Kehakiman menyatakan antara lain: ..."tidak dapat dipungkiri, sebagian besar rakyat Indonesia adalah pemeluk agama Islam". Agama

\footnotetext{
${ }^{12}$ Dikutip oleh M. Daud Ali, dalam Pengembangan Hukum Material Peradilan Agama, lihat Jurnal Mimbar Hukum: Aktualisasi Hukum Islam Nomor 17 Tahun V (Nov - Des 1994), Jakarta: Al-Hikmah dan Direktorat Pembinaan Badan Peradilan Agama Islam, 1994, hlm. 34
} 
Islam, kata Menteri Kehakiman, "mempunyai hukum Islam yang secara substansi terdiri atas dua bidang yaitu (1) bidang ibadah dan (2) bidang mu'amalah. Pengaturan bidang ibadah bersifat rinci, pengaturan mengenai mu'amalah atau mengenai segala aspek kehidupan masyarakat tidak bersifat rinci,yang ditemukan dalam bidang terakhir ini hanya prinsip-prinsipnya saja. Pembangunan dan aplikasi prinsip-prinsip bidang mu'amalah itu: diserahkan sepenuhnya kepada para penyelenggara negara dan pemerintahan yakni para ulil amri. Karena hukum Islam memegang peranan penting dalam membentuk dan membina ketertiban sosial umat Islam dan mempengaruhi segala segi kehidupannya, maka jalan terbaik yang dapat ditempuh ialah mengusahakan secara ilmiah transformasi norma-norma hukum Islam ke dalam hukum nasional, sepanjang menurut Menteri Kehakiman, sesuai dengan Pancasila dan Undang-Undang Dasar 1945 dan relevan dengan kebutuhan hukum khususnya umat Islam". Menurut Menteri Kehakiman, cukup banyak asas yang bersifat universal terkandung dalam hukum Islam yang dapat dipergunakan dalam menyusun hukum nasional.

\section{Kontribusi Hukum Islam dalam Pembangunan Hukum Nasional}

Sebagai upaya pembinaan dan pembangunan hukum nasional, hukum Islam telah memberikan kontribusi yang sangat besar, paling tidak dari segi jiwanya. Pernyataan ini diperkuat oleh beberapa argumen.

Pertama, UU No. I tahun 1974 tentang Perkawinan. Pada Pasal 2 Undang-undang ini, ditulis bahwa perkawinan adalah sah apabila dilakukan menurut hukum masing-masing agamanya. Sementara dalam pasal 63 menyatakan bahwa, yang dimaksud pengadilan dalam Undangundang ini adalah Pengadilan Agama bagi mereka yang beragama Islam.

Kedua, di dalam UU No.2 tahun 1989 tentang Sistem Pendidikan Nasional, disebutkan bahwa dalam rangka pembangunan manusia seutuhnya adalah beriman dan bertakwa kepada Tuhan Yang Maha Esa, berbudi pekerti luhur, mempunyai ilmu pengetahuan dan keterampilan, sehat rohani, mempunyai kepribadian yang mantap dan mandiri, mempunyai rasa tanggung jawab kemasyarakatan dan kebangsaan.

Ketiga, UU No. 7 tahun 1989 tentang Peradilan Agama. Undangundang ini membuktikan bahwa Peradilan Agama sudah sepantasnya hadir, tumbuh, serta dikembangkan di bumi Indonesia. Hal ini membuktikan adanya kontribusi umat Islam sebagai umat yang mayoritas. 
Keempat, Kompilasi Hukum Islam (KHI), meski tidak terbentuk undangundang, melainkan Instruksi Presiden Nomor I Tahun 1991. Kompilasi ini sangat membantu para hakim dalam memutuskan perkara, terutama di Peradilan Agama.

Kelima, PP No.28 tahun 1978 tentang Perwakafan Tanah Milik, di samping UU No.5 tahun 1960 sebagai pengaturan pokok masalah pertanahan di Indonsia. Sebagai pelaksanaannya telah dikeluarkan juga Peraturan Menteri Agama No. Tahun 1978 tentang Peraturan Pelaksana PP No. 28 tahun 1978. Untuk pelaksanaan tersebut telah dikeluarkan beberapa peraturan sebagai berikut : 1. Keputusan Menteri Agama No. 73 tahun 1978 tentang Pendelegasian Wewenang kepada Kepala Kanwil Departemen Agama Propinsi/Setingkat di seluruh Indonesia untuk mengangkat/memberhentikan Kepala KUA Kecamatan sebagai PAIW; 2. Instruksi bersama Menteri Agama dan Menteri Dalam Negeri masingmasing No. 1 tahun 1978 tentang Pelaksanaan Peraturan Pemerintah No. 28 tahun 1978; 3. Instruksi Menteri Agama No. 3 tahun 1979 tentang Petunjuk Pelaksanaan Keputusan Menteri Agama No. 73 tahun 1978 tentang Pendelegasian Wewenang kepada Kepala Kanwil Dep. Agama Propinsi/Setingkat untuk mengangkat/memberhentikan setiap Kepala KUA Kec. sebagai PPAIW; 4. Peraturan Direktur Jenderal Bimas Islam dan Urusan Haji No. D.II/5/Ed/14/1980 tentang Pemakaian Bea Materai dengan lampiran rekaman Surat Direktorat Jenderal Pajak No. S-629/ PJ.331/1080 tentang Ketentuan Menteri Keuangan atas tanda-tanda sebagai dimaksud dalam Peraturan Menteri Agama No. 1 Th. 1978 tentang Peraturan Pelaksanaan PP No. 28 Th. 1977; 5. Peraturan Menteri Dalam Negeri Nomor 6 tahun 1977 tentang Tata Cara Pendaftaran Tanah mengenai Perwakafan Tanah Milik. 6. Surat Dirjen Bimas Islam dan Urusan Haji No. D.II/5/Ed/07/1981 tentang Pendaftaran Perwakafan Tanah Milik; 7. Surat Dirjen Bimas Islam dan Urusan HajiNo. D.II/5/Ed/11/1981 tentang Petunjuk Pengisian nomor pada formulir Perwakafan Tanah Milik. ${ }^{13}$

Hukum Islam sebagai tatanan hukum yang dipedomani dan ditaati oleh mayoritas penduduk dan masyarakat Indonesia adalah hukum yang telah hidup dalam masyarakat, dan merupakan sebagian dari ajaran dan keyakinan Islam yang eksis dalam kehidupan hukum nasional, serta merupakan bahan dalam pembinaan dan pengembangannya.

${ }^{13}$ M. Yasir, Pelaksanaan Perwakafan di Indonesia, Permasalahan dan Pemecahannya, Fakultas Syariah UIN Jakarta; Jurnal Ahkam No. 16/VII/2005. hlm. 275 
Sejarah perjalanan hukum di Indonesia, kehadiran hukum Islam dalam hukum nasional merupakan perjuangan eksistensi. Teori eksistensi merumuskan keadaan hukum nasional Indonesia, masa lalu, masa kini, dan masa datang, menegaskan bahwa hukum Islam itu ada dalam hukum nasional Indonesia, baik tertulis maupun yang tidak tertulis. Ia ada dalam berbagai lapangan kehidupan hukum dan praktik hukum.

Teori eksistensi, dalam kaitannya dengan hukum Islam adalah teori yang menerangkan tentang adanya hukum Islam dalam hukum nasional Indonesia, yaitu: (1) Ada, dalam arti sebagai bagian integral dari hukum nasional Indonesia; (2) Ada, dalam arti kemandiriannya yang diakui, adanya kekuatan dan wibawanya, dan diberi status sebagai hukum nasional; (3) Ada, dalam arti hukum nasional dan norma hukum Islam yang berfungsi sebagai penyaring bahan-bahan hukum nasional di Indonesia; (4) Ada, dalam arti sebagai bahan utama dan unsur utama.

Jadi, secara eksistensial, kedudukan hukum Islam dalam hukum nasional merupakan sub sistem dari hukum nasional. Karenanya, hukum Islam juga mempunyai peluang untuk memberikan sumbangan dalam rangka pembentukan dan pembaharuan hukum nasional, meski harus diakui problema dan kendalanya yang belum pernah usai.

Secara sosiologis, kedudukan hukum Islam di Indonesia melibatkan kesadaran keberagaman bagi masyarakat, penduduk yang sedikit banyak berkaitan pula dengan masalah kesadaran hukum, baik norma agama maupun norma hukum, selalu sama-sama menuntut ketaatan.

Dengan demikian, jelaslah bahwa hubungan antara keduanya sangat erat. Keduanya sama-sama menuntut ketaatan dan kepatuhan dari warga masyarakat. Keduanya harus dikembangkan secara searah, serasi, dan seimbang. Keduanya tidak boleh dibiarkan saling bertentangan.

\section{Hukum Islam di Era Reformasi}

Di era reformasi lahir beberapa perundang-undangan yang dapat memperkokoh hukum Islam, di antaranya:

\section{Undang-undang Penyelenggaraan Ibadah Haji}

Undang-Undang Nomor 17 tahun 1999 tentang Penyelenggaraan Ibadah Haji disahkan dan diundangkan di Jakarta pada tanggal 3 Mei 1999 (Lembaran Negara Republik Indonesia Tahun 1999 Nomor 53 tambahan lembar negara Republik Indonesia Nomor 3832). 
Indonesia termasuk negara yang paling banyak jamaah hajinya. Sebab kuota yang ditentukan oleh Arab Saudi adalah 1 persen dari total jumlah penduduk suatu negara. Indonesia berpenduduk sekitar 250 juta, maka kuota haji sekitar 250 ribu jiwa.

Agar penyelenggaraan haji bisa berjalan lancar, tidak ada kesulitan, baik di dalam negeri maupun ketika di luar negeri, maka diperlukan manajemen yang baik. Apalagi haji dilaksanakan jauh dari negeri Indonesia, yaitu lebih dari 10.000 mil, melibatkan banyak orang dan departemen, dilaksanakan serentak dengan jutaan manusia dari seluruh dunia dalam satu tempat dan waktu yang sama. Untuk itu, pemerintah harus terlibat langsung dalam penyelenggaraannya, sebab menyangkut nama baik negara Indonesia.

Untuk mendukung upaya penyelenggaraan ibadah haji yang efektif, efisien dan terlaksana dengan sukses, maka pemerintah mengeluarkan Undang-Undang Nomor 17 tahun 1999 tentang Penyelenggaraan Ibadah Haji. Kemudian ditindaklanjuti dengan Keputusan Menteri Agama Nomor 224 tahun 1999 tentang Penyelenggaraan Ibadah Haji dan Umroh. Sebelum itu, pada masa penjajahan Belanda pernah berlaku perundangundangan penyelenggaraan haji, yaitu Ordonansi Haji (Pelgrims Ordonantie Staatsblad) tahun 1922 Nomor 698 termasuk perubahan dan tambahannya serta Pelgrims Verodening tahun $1938 .{ }^{14}$

Undang-undang Penyelenggaraan Ibadah Haji terdiri dari 15 Bab dan 30 Pasal. Secara global isinya sebagai berikut:

Bab I Ketentuan Umum (Pasal 1 - 3), Bab II Asas dan Tujuan (Pasal 4 - 5), Bab III Pengorganisasian (Pasal 6 - 8), Bab IV Biaya Penyelenggaraan Ibadah Haji (Pasal 9 - 11), Bab V Pendaftaran (Pasal 12 - 14), Bab VI Pembinaan (Pasal 15), Bab VII Kesehatan (Pasal 16), Bab VIII Keimigrasian (Pasal 17), Bab IX Transportasi (Pasal 18-20), Bab X Barang Bawaan (Pasal 21), Bab XI Akomodasi (Pasal 22), Bab XII Penyelenggaraan Ibadah Haji Khusus (Pasal 23 - 24), Bab XIII Penyelenggaraan Ibadah Umrah (Pasal 25 - 26), Bab XIV Ketentuan Pidana (Pasal 27 - 28), Bab XV Ketentuan Peralihan (Pasal 29), dan Bab XVI Ketentuan Penutup (Pasal 30).

\section{Undang-Undang Pengelolaan Zakat}

Undang-Undang Nomor 36 tahun 1999 tentang Pengelolaan Zakat disahkan dan diundangkan di Jakarta pada tanggal 23 September 1999

\footnotetext{
${ }^{14}$ Suparman Usman, Hukum Islam, Asas-asas dan Pengantar Studi Hukum Islam dan Tata Hukum Indonesia, Jakarta: Gaya Mediapratama, 2001, hlm. 187
} 
(Lembaran Negara Republik Indonesia Tahun 1999 Nomor 164, Tambahan Lembaran Negara Republik Indonesia Nomor 3885).

Negara menjamin warganya melaksanakan ajaran agamanya, melindungi fakir miskin dan untuk mewujudkan kesejahteraan masyarakat Indonesia sebagaimana tercantum dalam Pasal 5 ayat (1), Pasal 20 ayat (1), Pasal 29 dan Pasal 34 UUD 1945, maka pemerintah perlu membuat perangkat yuridis yang akan mendukung upaya tersebut. Kemudian lahirlah UU Nomor 38 tahun 1999 tentang Pengelolaan Zakat. Untuk melaksanakan UU tersebut muncul Keputusan Presiden Nomor 8 tahun 2001 tentang Badan Amil Zakat Nasional, yang di dalamnya mencantumkan perlunya tiga komponen untuk melaksanakan pengelolaan zakat, yaitu Badan Pelaksana, Dewan Pertimbangan dan Komisi Pengawas. Sebelum berlakunya UU di atas, sejak masa penjajahan Belanda sudah ada perundang-undangan yang berkaitan dengan zakat, yaitu Bijblad Nomor 2 tahun 1893 tanggal 4 Agustus 1893 dan Bijblad Nomor 6200 tanggal 28 Februari 1905. ${ }^{15}$

Dalam Peringatan Nuzulul Qur'an tahun 1422 H, Presiden Republik Indonesia Megawati Soekarnoputri telah mensosialisasikan Peraturan Pemerintah tentang kekeringan 2,5\% pajak bagi wajib pajak yang telah membayar zakat melalui Rekening Bank yang ditunjuk oleh Badan Amil Zakat Nasional. Bahkan hal tersebut sudah dilaksanakan di Dirjen Pajak.

UU Pengelolaan Zakat terdiri dari 10 Bab dan 25 pasal. Secara global isinya adalah sebagai berikut:

Bab I Ketentuan Umum (Pasal 1 - 3), Bab II Asas-asas dan Tujuan (Pasal 4 - 5), Bab III Organisasi Pengelolaan Zakat (Pasal 6 - 10), Bab IV Pengumpulan Zakat (Pasal 11 - 15), Bab V - Pendayagunaan Zakat (Pasal 16 - 17), Bab VI Pengawasan (Pasal VII Sanksi (Pasal 21), Bab VIII Ketentuan-ketentuan Lain (Pasal 22 - 23), Bab IX Ketentuan Peralihan (Pasal 24), Bab X (Pasal 25).

\section{Undang-Undang Wakaf}

Undang-Undang Nomor 41 Tahun 2004 tentang Wakaf disahkan dan diundangkan di Jakarta pada tanggal 27 Oktober 2004 oleh Presiden Susilo Bambang Yudoyono (Lembaran Negara Republik Indonesia Tahun 2004 Nomor 159).

Sebenarnya di Indonesia sudah ada beberapa Peraturan Perundangundangan tentang wakaf, antara lain adalah Peraturan Pemerintah Nomor

\footnotetext{
${ }^{15}$ Muchsin, Masa Depan Hukum Islam di Indonesia, Jakarta:STIH Iblam, 2004, hlm. 41
} 
28 Tahun 1997 tentang perwakafan tanah milik. Dalam Peraturan Pemerintah Nomor 28 Tahun 1997 itu hanya mengatur tentang wakaf sosial (wakaf umum) di atas tanah milik seseorang atau badan hukum. Tanah yang diwakafkan dalam Peraturan Pemerintah itu dibatasi hanya tanah milik saja, sedangkan hak-hak atas tanah lainnya seperti hak guna usaha, hak guna bangunan dan hak pakai tidak diatur. Di samping itu benda-benda lain seperti uang, saham dan lain-lain juga belum diatur dalam Peraturan Pemerintah. Oleh karena itu, pengembangan wakaf di Indonesia cukup tersendat-sendat.

Jika dibandingkan dengan beberapa peraturan perundang-undangan tentang wakaf ini terdapat beberapa hal baru dan penting. Beberapa di antaranya adalah mengenai masalah nazhir, harta benda yang diwakafkan (mauquf bih), dan peruntukan harta wakaf (mauquf 'alaih), serta perlunya dibentuk Badan Wakaf Indonesia. Berkenaan dengan masalah nazhir, karena dalam undang-undang ini yang dikelola tidak hanya benda tidak bergerak yang selama ini sudah lazim dilaksanakan di Indonesia, tetapi juga benda bergerak seperti uang, logam mulia, surat berharga, kendaraan, hak atas kekayaan intelektual, hak sewa dan lainlain, maka nazhirnya pun dituntut mampu untuk mengelola benda-benda tersebut.

Dalam undang-undang ini harta benda wakaf tidak dibatasi pada benda tidak bergerak saja tetapi juga benda bergerak seperti uang, logam mulia, surat berharga, kendaraan, hak atas kekayaan intelektual, hak sewa dan benda bergerak lain sesuai dengan ketentuan syari'ah dan peraturan perundang-undangan yang berlaku. Bahkan dalam undang-undang ini, wakaf uang diatur dalam bagian tersendiri. Dalam Pasal 28 UU ini disebutkan bahwa wewenang: a. melakukan pembinaan terhadap Nazhir dalam mengelola dan mengembangkan harta benda wakaf; b. melakukan pengelolaan dan pengembangan harta benda wakaf berskala nasional dan internasional; c. memberikan persetujuan dan atau izin atas perubahan peruntukan dan status harta benda wakaf; d. memberhentikan dan mengganti nazhir; e. memberikan persetujuan atas penukaran harta benda wakaf; f. memberikan saran dan pertimbangan kepada pemerintah dalam penyusunan kebijakan di bidang perwakafan.

Dalam pasal yang sama ayat (2) disebutkan bahwa dalam melaksanakan tugasnya BWI dapat bekerjasama dengan instansi Pemerintah baik Pusat maupun Daerah, organisasi masyarakat, para ahli, badan internasional, dan pihak lain yang dianggap perlu. 
Dilihat dari tugas dan wewenang BWI dalam UU ini nampak bahwa BWI mempunyai tanggung jawab untuk mengembangkan perwakafan di Indonesia sehingga nantinya wakaf dapat berfungsi sebagaimana disyariatkannya wakaf. Untuk itu orang-orang yang berada di BWI nantinya hendaknya memang orang-orang yang berkompeten di bidangnya masingmasing sesuai dengan yang dibutuhkan oleh badan tersebut. Satu hal yang penting dalam UU ini disebutkan bahwa peruntukan benda wakaf tidak semata-mata untuk kepentingan sarana ibadah dan sosial tetapi juga diarahkan untuk memajukan kesejahteraan umum dengan cara mewujudkan potensi dan manfaat ekonomi harta benda wakaf.

Hal itu memungkinkan pengelolaan harta benda wakaf dapat memasuki wilayah kegiatan ekonomi dalam arti luas sepanjang pengelolaan tersebut sesuai dengan prinsip manajemen dan ekonomi syari'ah. ${ }^{16}$

Undang-Undang Nomor 41 tahun 2004 tentang Wakaf terdiri dari XI Bab dan 71 pasal, Bab I Ketentuan Umum (1 pasal), Bab II Dasar-dasar Wakaf (30 pasal), Bab III Pendaftaran dan Pengumuman Harta Benda Wakaf (8 pasal), Bab IV Perubahan Status Harta Benda Wakaf (2 pasal), Bab V Pengelolaan dan Pengembangan Harta Benda Wakaf (5 pasal), Bab VI Badan Wakaf Indonesia (15 pasal), Bab VII Penyelesaian Sengketa (1 pasal), Bab VIII Pembinaan dan Pengawasan (4 pasal), Bab IX Ketentuan Pidana dan Sanksi Administratif (2 pasal), Bab X Ketentuan Peralihan (2 pasal), Bab XI Penutup (1 pasal).

\section{Undang-Undang Penyelenggaraan Keistimewaan di Aceh}

Undang-Undang Nomor 44 tahun 1999 tentang Penyelenggaraan Keistimewaan Daerah Aceh disahkan dan diundangkan di Jakarta pada tanggal 4 Oktober 1999 (Lembaran Negara Republik Indonesia tahun 1999 Nomor 172, Tambahan Lembaran Negara Republik Indonesia Nomor 3893).

Memasuki era reformasi, kemerdekaan mengeluarkan pendapat terbuka luas. Pemerintah pun sangat responsif terhadap aspirasi masyarakat kehidupan demokrasi berjalan dinamis.

Aspirasi rakyat Aceh yang selama Orde Baru tidak tersalurkan, kali ini mendapat respon yang luar biasa dari Pemerintah. Kehidupan rakyat

${ }^{16}$ Farida Prihantini, dkk, Hukum Islam Zakat dan Wakaf Teori dan Prakteknya di Indonesia, Jakarta: Papan Sinar Sinanti \& FHUI, 2005, hlm. 135 
Aceh yang religius, menjunjung tinggi adat, dan telah menempatkan ulama pada peran yang sangat terhormat dalam kehidupan masyarakat, berbangsa dan bernegara perlu dilestarikan dan dikembangkan.

Untuk itu, akhirnya pemerintah memberikan jaminan kepastian hukum dalam penyelenggaraan keistimewaan yang dimiliki rakyat Aceh sebagaimana tersebut di atas dengan munculnya Undang-Undang Nomor 44 tahun 1999 tentang Penyelenggaraan Keistimewaan Propinsi Daerah Istimewa Aceh.

UU Nomor 44 tahun 1999 terdiri dari 5 Bab dan 13 pasal. Secara garis besar isinya sebagai berikut: Bab I Ketentuan Umum (Pasal 1), Bab II Kewenangan (Pasal 2), Bab III Penyelenggaraan Keistimewaan (Pasal 3 11), Bab IV Ketentuan Peralihan (Pasal 12), Bab V Ketentuan Penutup (Pasal 13).

\section{Undang-Undang Otonomi Khusus di Aceh}

Undang-Undang Nomor 18 Tahun 2001 tentang Otonomi Khusus Propinsi Daerah Istimewa Aceh Sebagai Propinsi Nanggroe Aceh Darussalam disahkan dan diundangkan di Jakarta pada tanggal 9 Agustus 2001 (Lembaran Negara Republik Indonesia Tahun 2001 Nomor 114, Tambahan Lembaran Negara Republik Indonesia Nomor 4134).

Sistem Pemerintah Negara Kesatuan Republik Indonesia menurut UUD 1945 mengakui dan menghormati satuan-satuan Pemerintah Daerah yang bersifat khusus atau istimewa yang diatur dalam Undang-undang.

Seiring dengan munculnya era reformasi serta aspirasi rakyat Aceh, Pemerintah memberikan otonom khusus. Sehubungan dengan itu ditetapkan Undang-Undang Nomor 18 tahun 2001 tentang Otonomi Khusus Propinsi Daerah Istimewa Aceh Sebagai Propinsi Nanggroe Aceh Darussalam.

Melihat karakter sosial dan masyarakat Aceh dengan budaya Islam yang kuat, dan telah memberikan semangat juang yang tinggi pada masa perjuangan memperebutkan kemerdekaan negara Indonesia. Maka seiring dengan munculnya era reformasi serta aspirasi rakyat Aceh. Pemerintah memberikan otonomi khusus. Sehubungan dengan itu ditetapkan Undangundang Nomor 18 tahun 2001 tentang Otonomi Khusus Propinsi Daerah Istimewa Aceh Darussalam.

Undang-Undang Nomor 18 tahun 2001 tersebut terdiri dari 14 Bab yang terinci dalam 34 pasal. Adapun secara global isinya sebagai berikut:

Bab I Ketentuan Umum (Pasal 1), Bab II Susunan dan Kedudukan Propinsi Nanggroe Aceh Darussalam (Pasal 2), Bab III Kewenangan 
Propinsi Nanggroe Aceh Darussalam (Pasal 3), Bab IV Keuangan Propinsi Aceh Nanggroe Darussalam (Pasal 4 - 7), Bab V Lambang termasuk Alam di Propinsi Nanggroe Aceh Darussalam (Pasal 8), Bab VI Lembaga Legislatif Propinsi Nanggroe Aceh Darussalam (Pasal 9), Bab VII Wali Nanggroe dan Tuha Nanggroe sebagai Penyelenggara Adat, Budaya, dan Pemersatu Masyarakat (Pasal 10), Bab VIII Badan Eksekutif Propinsi Nanggroe Aceh Darussalam (Pasal 11 - 16), Bab IX Pemilih dan Hak Pemilik (Pasal 17 - 20), Bab X Kepolisian Daerah Propinsi Nanggroe Aceh Darussalam (Pasal 21 - 23), Bab XI Kejaksanaan Propinsi Nanggroe Aceh Darussalam (Pasal 24), Bab XII Mahkamah Syari'ah Propinsi Nanggroe Aceh Darussalam (Pasal 25 - 26), Bab XIII Ketentuan Peralihan (Pasal 27 - 30), dan Bab XIV (Pasal 31 - 34).

Dengan lahirnya Undang-Undang Nomor 18 tahun 2001 tentang Otonomi Khusus Propinsi Daerah Istimewa Aceh, salah satunya dalam bidang hukum, maka baru-baru ini telah disahkan Qanun (Perda) Nomor 13 tahun 2003 tentang Judi, Nomor 14 tahun Minuman Keras, Nomor 15 tahun 2003 tentang Hal Mesum dan telah diterapkan Hukuman Cambuk.

\section{Perbankan Syari'ah}

Walaupun baru dalam Draf RUU Perbankan Syariah, tetapi di dalam Undang-Undang Nomor 10 Tahun 1998 tentang Perbankan menguatkan kedudukan hukum Islam seperti pada pasal 1, 6, 7, 8, 11 dan 13. pasalpasal tersebut menjelaskan tentang dual system perbankan (konvensional dan syariah).

\section{Undang-Undang No. 3 Tahun 2006 tentang Perubahan atas Undang- Undang No. 7 tahun 1989 tentang Peradilan Agama}

Pada tanggal 28 Februari 2006, UU No. 7 tahun 1989 tentang Peradilan Agama telah diamandemen melalui UU No. 3 tahun 2006 tentang Perubahan atas UU No. 7 tahun 1989 (Lembaran Negara Republik Indonesia tahun 2006 Nomor 22). Perubahan tersebut dilakukan karena UU No. 7 tahun 1989 tidak sesuai lagi dengan perkembangan kebutuhan hukum masyarakat dan kehidupan ketatanegaraan menurut UUD 1945. Sesuai amanat konstitusi Pasal 24 ayat (2), bahwa Peradilan Agama merupakan salah satu lingkungan peradilan yang berada di Mahkamah Agung bersama peradilan lainnya di lingkungan Peradilan Umum, Peradilan Tata Usaha Negara dan Peradilan Militer. Begitu juga ketentuan 
Pasal 10 ayat (2) UU No. 4 tahun 2004 tentang Kekuasaan Kehakiman, bahwa badan peradilan yang berada di Mahkamah Agung meliputi badan peradilan dalam lingkungan Peradilan Umum, Peradilan Agama, Peradilan Militer dan Peradilan Tata Usaha Negara. Oleh karena itu berlaku kebijakan satu atap. Sejak tahun 2004, Peradilan Agama berpindah induk dari Departemen Agama ke Mahkamah Agung. Wahyu Widiana, yang tadinya bertugas sebagai direktur peradilan Islam di departemen Agama ditarik ke Mahkamah Agung dan menduduki Dirjen Peradilan Agama.

UU No. 4 tahun 2004 secara tegas telah mengatur pengalihan organisasi, administrasi, dan finansial dari semua lingkungan peradilan ke Mahkamah Agung. Dengan demikian organisasi, administrasi, finansial badan peradilan di lingkungan Peradilan Agama yang sebelumnya berada di bawah Departemen Agama berdasarkan UU No. 7 tahun 1989 disesuaikan dengan UU No. 3 tahun 2006.

UU No. 4 tahun 2004 menegaskan adanya pengadilan khusus yang dibentuk dalam salah satu lingkungan peradilan dengan undang-undang. Oleh karena itu, keberadaan pengadilan khusus dalam lingkungan Peradilan Agama diatur pula dalam UU No. 3 tahun 2006, yaitu Peradilan Syari'ah Islam di Nangroe Aceh Darussalam.

Kewenangan Peradilan Agama yang semula bertugas dan berwenang memeriksa, memutus dan menyelesaikan perkara-perkara tingkat pertama antara orang-orang yang beragama Islam di bidang: a. Perkawinan, $b$. Kewarisan, wasiat dan hibah, c. Waqaf dan shadaqah. Berdasarkan UU No. 3 tahun 2006 kewenangannya diperluas dalam bidang ekonomi syari'ah meliputi: Bank Syari'ah, Asuaransi, Asuransi Syari'ah, Reasuransi Syari'ah dan Surat Berharga Berjangka Menengah Syari'ah, Sekuritas Syari'ah, Pengadilan Syari'ah, Dana Pensiun Lembaga Keuangan (DPLK) Syari'ah, Bisnis Syari'ah dan Lembaga Keuangan Mikro Syari'ah.

Dalam beberapa tahun belakangan ini perkembangan bidang-bidang ekonomi syari'ah memang pesat. Ini yang akan menjadi problem ke depan. Transaksi bisnis syari' ah bukan saja dilakukan oleh orang yang beragama Islam, tetapi juga sangat mungkin antara orang Islam dan bukan Islam. Problemnya, apakah Peradilan Agama berwenang menangani sengketa Syari'ah antara orang Islam dengan yang bukan Islam. Problem semacam ini juga ditemukan dalam waris beda agama.

Oleh karena itu dalam penjelasan Pasal 49 UU No. 3 tahun 2006, dijelaskan bahwa yang dimaksud dengan "antara orang-orang yang 
beragama Islam adalah termasuk orang atau badan hukum uyang dengan sendirinya menundukan diri dengan sukarela kepada hukum Islam mengenai hal-hal yang menjadi kewenangan Peradilan Agama sesuai dengan ketentuan Pasal 49.

Dalam UU Nomor 7 tahun 1989 berlaku azaz Choise of law (pilihan hukum), yakni dalam bidang kewarisan, para pihak yang beragama Islam sebelum berperkara dapat mempertimbangkan untuk memilih hukum apa yang dipergunakan dalam pembagian warisan. Ketentuan ini dalam UU No. 3 tahun 2006 tidak berlaku lagi. Sehingga orang Islam yang berperkara sesama orang Islam dalam bidang kewarisan menjadi wewenang Peradilan Agama.

Kewenangan lain yang diatur dalam UU No. 3 tahun 2006, bahwa Peradilan Agama berwenang memeriksa dan memutus sengketa milik atau keperdataan lain yang terkait dengan objek sengketa yang diatur Pasal 49, apabila subjek sengketa orang-orang yang beragama Islam. Hal ini untuk menghindari upaya memperlambat atau mengulur waktu penyelesaian sengketa karena alasan adanya sengketa milik atau keperdataan lainnya tersebut sering dibuat oleh pihak yang merasa dirugikan dengan adanya gugatan ke Pengadilan Agama. Sebaliknya apabila subjek yang mengajukan sengketa hak milik atau keperdataan lain tersebut bukan menjadi subjek bersengketa di Peradilan Agama, sengketa di Pengadilan Agama ditunda untuk menunggu putusan gugatan yang diajukan ke pengadilan yang di lingkungan Peradilan Umum. Penangguhan dimaksud hanya dilakukan jika pihak yang berkeberatan telah mengajukan bukti ke Pengadilan Agama bahwa telah didaftarkan gugatan di peradilan negeri terhadap objek sengketa di Pengadilan Agama. Dalam hal objek sengketa yang diajukan keberatannya, Peradilan Agama tidak perlu menangguhkan putusannya, terhadap objek sengketa yang tidak terkait dimaksud.

Tambahan lain tentang kewenangan Peradilan Agama adalah bahwa Pengadilan Agama memberikan itsbat kesaksian rukyat hilal dalam penentuan awal bulan pada tahun Hijriyah. Hal ini diatur dalam UU No. 3 tahun 2006, karena selama ini Pengadilan Agama memberikan penetapan (Itsbat) terhadap kesaksian orang yang telah melihat atau menyaksikan hilal bulan pada setiap memasuki bulan Ramadhan dan awal bulan Syawal tahun Hijriyah dalam rangka Menteri Agama mengeluarkan penetapan secara nasional untuk penetapan 1 (satu) Ramadhan dan 1 (satu) Syawal. Pengadilan Agama juga dapat memberikan keterangan atau nasehat mengenai perbedaan penentuan arah kiblat dan penentuan waktu shalat. 
Perkembangan kewenangan tersebut terkait erat dengan kesiapan aparat, termasuk hakim dan panitera. Pemahaman hakim tentang ekonomi syari'ah mutlak diperlukan. Oleh karena hadirnya UU No. 3 tahun 2006 diharapkan dapat memberikan inspirasi para penegak hukum di lingkungan Peradilan Agama untuk lebih meningkatkan kinerja dan kualitas sumber dayanya dalam rangka memberikan pelayanan publik di bidang hukum secara optimal.

Hal yang perlu menjadi perhatian adalah eksistensi Peradilan Agama yang telah mendapat pengakuan secara konstitusional . Dengan masuknya Peradilan Agama ke dalam UUD 1945, tidak akan ada perdebatan lagi mengenai kehadiran peradilan agama dalam sistem kekuasaan kehakiman di Negara Kesatuan Republik Indonesia.

\section{Kendala dan Problematika Hukum Islam di Indonesia}

Pembangunan hukum diarahkan pada terwujudnya sistem hukum nasional yang menjadi kepentingan nasional, dengan penyusunan awal materi hukum secara menyeluruh yang bersumber pada Pancasila dan UUD 1945. Karena itu, perlu ditegaskan bahwa penyusunan program legislatif nasional, termasuk upaya pergantian peraturan perundang-undangan yang bersumber pada Pancasila dan UUD 1945, merupakan upaya cerdas dalam proses perwujudan hukum nasional yang dijiwai oleh nilai-nilai nasional dan keagamaan bangsa Indonesia.

Pemikiran akan terjadi perubahan hukum nasional itu, sebenarnya suatu manifestasi dari kehendak melepaskan diri dari kehidupan yang tidak demokratis, fasistis dan represif. Pikiran itu merupakan pergumulan dialektis dari kekuatan yang tidak puas dengan sistem hukum warisan kolonial yang tidak sejalan dengan nilai-nilai sosial kultural Indonesia.

Konsep ini terukir dalam sejarah dan nilai-nilai perjuangan bangsa yang dikristalisasikan dalam konsensus Piagam Jakarta, sebagai titik kulminasi yang menjiwai dan mencetuskan Proklamasi Kemerdekaan 17 Agustus 1945. Hal ini menunjukkan bahwa hukum Islam sudah mempunyai akar historis yang sangat jauh ke jiwa bangsa Indonesia.

Di samping peluang sosiologis sebagaimana yang dinyatakan di atas, Hukum Islam juga memiliki beberapa kendala dan problema, utamanya menyangkut integritasnya ke dalam hukum nasional yaitu: ${ }^{17}$

${ }^{17}$ Said Agil Husin al-Munawar, Hukum Islam dan Pluralitas Sosial, Jakarta: Penamadani, 2004, hlm. 17 
Pertama, kemajemukan bangsa. Patut diingat bahwa negara Indonesia memiliki wilayah yang sangat luas, masing-masing memiliki kondisi sosial dan kultural sendiri-sendiri sehingga tidak mudah untuk mendekatkannya satu sama lain. Tetapi, upaya pengintegrasian aspek sosio-kultural masingmasing elemen bangsa ini ke dalam sistem hukum nasional, harus didahului dengan proses pemilahan pada bidang-bidang yang dilakukan direunifikasikan secara relevan.

Kedua, metode pendidikan hukum. Selama ini, pelajaran ilmu hukum yang diajarkan kepada mahasiswa adalah trikotomi antara hukum Barat, hukum Islam, dan hukum adat. Berhubungan dengan masyarakat Indonesia relatif heterogen dan wilayahnya cukup luas, maka semakin berakibat pencarian titik temu di antara elemen hukum-hukum tersebut. Jadi, diperlukan sekarang adalah pemahaman integral dari pakar hukum dari ketiga sumber hukum tadi. Itu sudah pasti memerlukan perjuangan intelektual yang sangat berat.

Ketiga, kurangnya pengkajian akademik di bidang hukum Islam. Ketertinggalan dalam mengembangkan pusat-pusat pengkajian Islam disebabkan oleh: (a) secara historis, pusat pengkajian yang tidak menghargai hukum Islam yang lebih dahulu berkembang ternyata tidak memberi tempat bagi pengkajian hukum Islam; (b) pengkajian hukum Islam terletak di antara pengkajian ilmu agama dan pengkajian ilmu hukum, akibatnya aspek pengkajiannya tidak mendalam; (c) perkembangan kualitas ketaatan umat Islam yang lemah, terutama keyakinan akidah dan moral yang sulit dikendalikan sehingga menimbulkan penurunan kualitas moral dalam pelaksanaan hukum; (d) masih dianutnya kebijaksanaan hukum politik Belanda yang mempunyai kepentingan politik sendiri, seperti: (1) umat Islam tidak boleh tunduk kepada hukumnya sendiri, (2) belum sepenuhnya kemandirian Peradilan Agama dalam sengketa perdata kecuali hukum keluarga; (e) banyak masalah yang dihadapi umat Islam, sementara belum ada fatwa hukum yang mampu merangkumkannya dalam satu perundangundangan yang bisa diterima oleh semua elemen masyarakat Islam.

Inilah masalah-masalah yang dihadapi umat Islam dewasa ini, tatkala umat ini ingin memberikan kontribusi hukum Islam dalam proses pembangunan hukum nasional. 


\section{Penutup}

Dalam perjalanannya, hukum Islam mengalami perkembangan yang signifikan. Masih banyak peluang hukum Islam masuk dalam perundangundangan di Indonesia. Saat ini telah nampak adanya fenomena perkembangan yang positif dalam penerimaan masyarakat, elit penguasa, dan legislatif terhadap kehendak legislasi hukum Islam.

\section{Daftar Pustaka}

Amir Syarifuddin, "Pengertian dan Sumber Hukum Islam", dalam Falsafah Hukum Islam, Jakarta: Bumi Aksara, 1992

Amiur Nuruddin dan Azhari Akmal Tarigan, Hukum Perdata Islam di Indonesia, Jakarta: Kencana, 2004

AS. Honrby, Oxford Advanced Learner's Dictionary of Current English, Britain: Oxford University Press, 1986

Farida Prihantini, dkk, Hukum Islam Zakat dan Wakaf Teori dan Prakteknya di Indonesia, Jakarta: Papan Sinar Sinanti \& FHUI, 2005

Hamka, Antara Fakta dan Khayal "Tuanku Rao", Jakarta: Bulan Bintang, 1974

Ichtijanto, "Pengembangan Teori Berlakunya Hukum Islam di Indonesia", dalam, Hukum Islam di Indonesia Perkembangan dan Pembentukan, Bandung: Rosdakarya, 1991

Ismail Sunny, "Tradisi dan Inovasi Keislaman di Indonesia dalam Bidang Hukum Islam", dalam, Hukum Islam dalam Tatanan Masyarakat Indonesia, Cik Hasan Bisri (ed), Jakarta: Logos Publishing, 1988

Joseph Schacht, An Introduction to Islamic Law, Oxford: University Press, 1964

M. Daud Ali, dalam Pengembangan Hukum Material Peradilan Agama, lihat Jurnal Mimbar Hukum: Aktualisasi Hukum Islam Nomor 17 Tahun V (Nov - Des 1994), Jakarta: Al-Hikmah dan Direktorat Pembinaan Badan Peradilan Agama Islam, 1994

M. Yahya Harahap, Informasi Materi Kompilasi Hukum Islam: "Mempositifkan Abstraksi Hukum Islam", dalam, Kompilasi Hukum Islam dan Peradilan Agama dalam Sistem Hukum Nasional, Jakarta, Logos, 1999

Muchsin, Masa Depan Hukum Islam di Indonesia, Jakarta: STIH Iblam, 2004

Muhammad Hasbi Ash-Shiddiqy, Falsafah Hukum Islam, Jakarta: Bulan Bintang, 1993

Said Agil Husin al-Munawar, Hukum Islam dan Pluralitas Sosial, Jakarta: Penamadani, 2004 
Sayuti Thalib, Receptie a Contrario, Jakarta: Bina Aksara, 1985

Suparman Usman, Hukum Islam, Asas-asas dan Pengantar Studi Hukum Islam dan Tata Hukum Indonesia, Jakarta: Gaya Mediapratama, 2001

Supomo dan Djoko Sutowo, Sejarah Politik Hukum Adat 1609 - 1848, Jakarta: Djambatan 1955 